\title{
ROLE OF VARMAM THERAPY IN KUMBAVATHAM MANAGEMENT
}

\author{
MAANICKHA CHELVI KS ${ }^{1 *}$, RAJESH KUMAR ${ }^{2}$, RAJENDRA KUMAR A ${ }^{1}$
}

${ }^{1}$ Siddha Regional Research Institute (CCRS), Puducherry, India. ${ }^{2}$ Siddha Central Research Institute (CCRS), Chennai, Tamil Nadu, India. Email: manickaselvi@hotmail.com

Received: 12 May 2016, Revised and Accepted: 23 May 2016

\section{ABSTRACT}

Introduction: Siddha medicine, one among the ancient indigenous medical systems of India, has a repository of classical formulations as internal medication and various other unique techniques/therapies as external usage. Varmam is one among such therapies used to treat multiple ailments, especially related to musculoskeletal and neurological deficits. Sometimes, varmam therapy is used along with internal medications and external applications as well.

Objective: Adhesive capsulitis or periarthritis may be correlated with kumbavatham which is one of the vatha diseases mentioned in the Siddha literature Yugi Vaithya Chinthamani. Kumbavatham is one of the most common rheumatological problems in old age group, especially those in diabetic participants. It is the most common long-term complication next to osteoarthritis in diabetes mellitus patients.

Methods: The present intervention was done in kumbavatham patients who volunteered to undergo the varmam therapy with regular outpatient department medications, and the results were presented. The effect of varmam therapy on kumbavatham was assessed in accordance with shoulder pain and disability index.

Result and Conclusion: The result of the current study concludes that the varmam therapy might be useful in the management of kumbavatham diseases and thus improves the quality of life of the patients.

Keywords: Kumbavatham, Adhesive capsulitis, Varmam therapy, Diabetes mellitus, Siddha.

(C) 2016 The Authors. Published by Innovare Academic Sciences Pvt Ltd. This is an open access article under the CC BY license (http://creativecommons org/licenses/by/4. 0/) DOI: http://dx.doi.org/10.22159/ajpcr.2016.v9s2.12783

\section{INTRODUCTION}

Siddha system is originated in southern part of India, which is one of the ancient traditional systems of medicine. This system has its own unique methodology of treatment for various ailments. Varmam is one among such therapies used to treat multiple ailments, especially related to musculoskeletal and neurological deficits. This helps the suffering community either acting by locally or regulating the three humors, i.e., Vali, Azhal, and Iyam. Varmam therapy can also be used along with internal medications and external applications as well. Varmam is the points wherever the energy (pranan) is stored, and when particular area or organ is affected, the energy will spread to that area and make that organ function effectively. This treatment methodology is taught by the guru-disciple method (Gurukulam). The guru who teaches varmam is called as "Varmani or Asan." According to Siddha principles, the movements of the body are mainly controlled by Vali. Hence, the varmam points were also classified as Vali, Azhal, and Iyam varmam points [1].

Kumbavatham (periarthritis or adhesive capsulitis) is a common cause of shoulder pain and disability. In Siddha text Yugi Vaithya Chinthamani, it was mentioned as pain in the shoulder and upper limb, pricking pain in the cheek and jaw region, and inability in flexion and extension [2].Adhesive capsulitis is characterized by pain, stiffness, and limited function of the glenohumeral joint [3], which adversely affects the entire upper extremity. Patients typically describe onset of shoulder pain followed by a loss of motion [4], and the most common limitations in range of motion are flexion, abduction, and external rotation. Approximately $70 \%$ of frozen shoulder patients were women [5]; however, males with frozen shoulder were at greater risk for longer recovery and greater disability $[3,5]$

The aim of the present study was to evaluate the effect of varmam therapy on kumbavatham management. The result of the present study may help in the betterment of disease management.

\section{METHODS}

Study design and subjects

This pilot study was done in 17 participants (single group) who visited the outpatient department of Siddha Regional Research Institute (CCRS), Puducherry. The study was conducted for a period of 2 weeks. Both inclusion and exclusion criteria for the patients were mentioned below.

\section{Inclusion criteria}

1. Age between 35 and 65 years

2. With or without diabetic

3. Unilateral or bilateral involvement

4. Both sexes

\section{Exclusion criteria}

1. Age below 35 and above 65 years

2. Traumatic history

3. Fracture within the glenohumeral joint

4. Other type of systemic involvement such as gouty, rheumatoid arthritis, SLE, and psoriatic arthritis

5. Attended varmam therapy $<5$ sittings.

\section{Therapeutic schedule}

The following varmam points were stimulated 1 time/day for 5 days. The pressure is mentioned in varmam literatures.

\section{Varmam points [6-10]}

- Mozhi piralgai (Sondhari varmam - midpoint of interdigital cleft between middle and ring finger).

- Kavuli kaalam (webspace (dorsal side) between the thumb and index finger PI.L. $\mathrm{LI}_{\mathrm{h}-3}$ ).

- Chavvu varmam (Mundaga varmam- six fingerbreadth above from midpoint of the elbow joint (anterior side) A.L.UI

- Enthi kaalam (one fingerbreadth anterior to midpoint of the axilla. Am. $\left.\mathrm{L}_{4} \mathrm{UI}_{\mathrm{S}-8}\right)$. 
Table 1: SPADI index score before and after treatment

\begin{tabular}{|c|c|c|c|c|c|c|}
\hline \multirow[t]{2}{*}{ S.N } & \multirow[t]{2}{*}{ Name } & \multirow[t]{2}{*}{ Age/sex } & \multicolumn{2}{|l|}{ Before treatment } & \multicolumn{2}{|l|}{ After treatment } \\
\hline & & & Pain scale score (\%) & Disability scale score (\%) & Pain scale score (\%) & Disability scale score (\%) \\
\hline 1 & Case 1 & $67 / \mathrm{M}$ & 78 & 46.25 & 30 & 25 \\
\hline 2 & Case 2 & $63 / F$ & 66 & 52.5 & 10 & 13.75 \\
\hline 3 & Case 3 & $55 / \mathrm{F}$ & 76 & 77.5 & 24 & 31.25 \\
\hline 4 & Case 4 & $48 / \mathrm{M}$ & 80 & 78.8 & 26 & 25 \\
\hline 5 & Case 5 & $65 / F$ & 72 & 72.5 & 32 & 38.75 \\
\hline 6 & Case 6 & $60 / \mathrm{M}$ & 52 & 46.25 & 30 & 17.5 \\
\hline 7 & Case 7 & $49 / \mathrm{F}$ & 86 & 73.8 & 26 & 28.8 \\
\hline 8 & Case 8 & $60 / \mathrm{F}$ & 54 & 50 & 24 & 26.25 \\
\hline 9 & Case 9 & $40 / \mathrm{F}$ & 48 & 60 & 10 & 21.25 \\
\hline 10 & Case 10 & $46 / \mathrm{F}$ & 72 & 77.5 & 28 & 23.75 \\
\hline 11 & Case 11 & $39 / \mathrm{F}$ & 70 & 78.75 & 36 & 38.75 \\
\hline 12 & Case 12 & $52 / \mathrm{F}$ & 68 & 65 & 40 & 26.25 \\
\hline 13 & Case 13 & $53 / \mathrm{F}$ & 68 & 65 & 22 & 21.25 \\
\hline 14 & Case 14 & $45 / F$ & 78 & 71.25 & 32 & 28.75 \\
\hline 15 & Case 15 & $55 / \mathrm{F}$ & 64 & 65 & 26 & 17.5 \\
\hline 16 & Case 16 & $60 / F$ & 70 & 71.25 & 28 & 36.25 \\
\hline 17 & Case 17 & $60 / \mathrm{F}$ & 88 & 81.1 & 32 & 25 \\
\hline
\end{tabular}

SPADI: Shoulder pain and disability index

Table 2: Descriptive statistics

\begin{tabular}{lllll}
\hline Paired samples statistics & & & & \\
\hline Variable & Mean & N & Standard deviation & Standard error mean \\
\hline Pair 1 & 70.0000 & 17 & 11.11306 & 2.69531 \\
$\quad$ Pain scale score (\%) before & & & 7.78007 & 1.88694 \\
$\quad$ treatment & 26.8235 & 17 & & \\
\hline
\end{tabular}

Table 3: Effect of varmam treatment in kumbavatham

\begin{tabular}{|c|c|c|c|c|c|c|c|}
\hline \multicolumn{8}{|c|}{ Paired samples test } \\
\hline \multirow[t]{3}{*}{ Variable } & \multicolumn{4}{|l|}{ Paired differences } & \multirow[t]{3}{*}{$\mathbf{T}$} & \multirow[t]{3}{*}{ df } & \multirow{3}{*}{$\begin{array}{l}\text { Significant } \\
\text { (two-tailed }\end{array}$} \\
\hline & \multirow[t]{2}{*}{ Mean \pm SD } & \multirow{2}{*}{$\begin{array}{l}\text { Standard } \\
\text { error mean }\end{array}$} & \multicolumn{2}{|c|}{$95 \%$ confidence interval of the difference } & & & \\
\hline & & & Lower & Upper & & & \\
\hline \multicolumn{8}{|l|}{ Pair 1} \\
\hline Pain_BF-Pain_AT & $43.17647 \pm 10.74846$ & 2.60688 & 37.65012 & 48.70282 & 16.562 & 16 & 0.000 \\
\hline
\end{tabular}

- Piratharai (near to armpit in posterior side Pm. $\mathrm{L}_{3} \mathrm{UI}_{\mathrm{s}-8}$ ).

- Kakkatai Kaalam (midway between the neck and head of arms, four fingers above from midline of the clavicle).

- Kaiketti varmam (two fingerbreadth below from medial angle of the scapula, P. $L_{3 .} \mathrm{T}_{5}$ ).

\section{Assessment tools}

Shoulder pain and disability index (SPADI) [11,12].

\section{Procedure}

Patients with kumbavatham (periarthritis) who were fulfilling both the inclusion and exclusion criteria and volunteered to participate in this study were assessed through SPADI index, and the data were recorded. Patients were asked to visit outpatient department (OPD) for consecutive five sittings of varmam therapy. They were also treated with regular OPD medications both internal and external (medicated oils). Before the treatment, the disability scale is recorded by SPADI, and all the movements with angle were recorded clinically. After five sittings of varmam therapy, the patient was examined for prognosis.

\section{RESULTS AND DISCUSSION}

Before initiating the treatment, both pain and disability in doing regular household works were scored based on patient words. After varmam therapy, improvements were noted again from the words of patients.
Range of movements was also assessed both before and after varmam therapy. The SPADI scores of total 17 patients, both before and after 5 days of varmam therapy, were recorded and were listed in Table 1.

\section{Analysis of pain scale percentage}

The changes in pain and disability percentage observed before and after varmam treatment were listed in Table 2 . It was then tested for the null hypothesis $\mathrm{H}_{0}$ : There is no difference in pain and disability percentage before and after treatment versus alternate hypothesis $\mathrm{H}_{1}$ : There is difference in pain and disability percentage before and after treatment using the paired $t$-test at $5 \%$ level of significance. After varmam therapy, the pain and disability percentage have been improved and found to be highly statistically significant $(* \mathrm{p}=0.000)$ and was depicted in Table 3 . Hence, there is an evidence to reject the $\mathrm{H}_{0}$ and for the tested number of patients; there was a significant difference in pain and disability score before and after varmam treatment. Before varmam therapy, the pain and disability score were averagely more than $70 \%$. However, after five sittings of varmam therapy, it was averagely reduced to $30 \%$. The quality of life was also improved well after 5 days of treatment. During the full course, no complaints about adverse effect or non-responsiveness were reported.

\section{CONCLUSION}

From this study, it was observed that the varmam therapy has decreased the pain and disability score in kumbavatham patients. Along with 
OPD medications (internal and external), this external therapy has changed their quality of life significantly in 5 days. varmam therapy has facilitated their ADLs also. Hence, it may be concluded that varmam therapy may play a positive role in the management of kumbavatham.

\section{REFERENCES}

1. Rajaram RK. Varma Maruthuva Adippadaigal. Pudukkadai, PO A.T.SV.S. Siddha Maruthuva Kallori; 2008. p. 1-78.

2. Shanmugavelu M. Podhu Maruthuvam. Chennai: Directorate of Indian Medicine; 2012. p. 583

3. Grey RG. The natural history of "idiopathic" frozen shoulder. J Bone Joint Surg Am 1978;60(4):564.

4. Boyle-Walker KL, Gabard DL, Bietsch E, Masek-VanArsdale DM, Robinson BL. A profile of patients with adhesive capsulitis. J Hand Ther 1997;10(3):222-8.

5. Sheridan MA, Hannafin JA. Upper extremity: Emphasis on frozen shoulder. Orthop Clin North Am 2006;37(4):531-9.

6. Rajaram RK. Varma Pulligalin Iruppidam. Pudukkadai, PO: A.T.SV.S. Siddha Maruthuva Kallori; 2008. p. 188, 321, 57-88.

7. Rajaram RK. Varma Maruthuvam Sirappu. Pudukkadai, PO: A.T.SV.S Siddha Maruthuva Kallori; 2008. p. 335-8, 51, 71.

8. Varma S. Foot prints of medical varmalogy. Verses 134. Coimbatore: Arts Research Institute; 2012. p. 969-70.

9. Varma N. Foot prints of medical varmalogy. Verses 310. Coimbatore: Arts Research Institute; 2012. p. 500.

10. Vedhasathi Ennum Varmakalai. Coimbatore: Thirumoolar Varmam Therapy \& Research Institute; 2012.

11. MacDermid JC, Solomon P, Prkachin K. The Shoulder Pain and Disability Index demonstrates factor, construct and longitudinal validity. BMC Musculoskelet Disord 2006;7:12.

12. Tveitå EK, Ekeberg OM, Juel NG, Bautz-Holter E. Responsiveness of the shoulder pain and disability index in patients with adhesive capsulitis. BMC Musculoskeletal Disord 2008;9:16. 